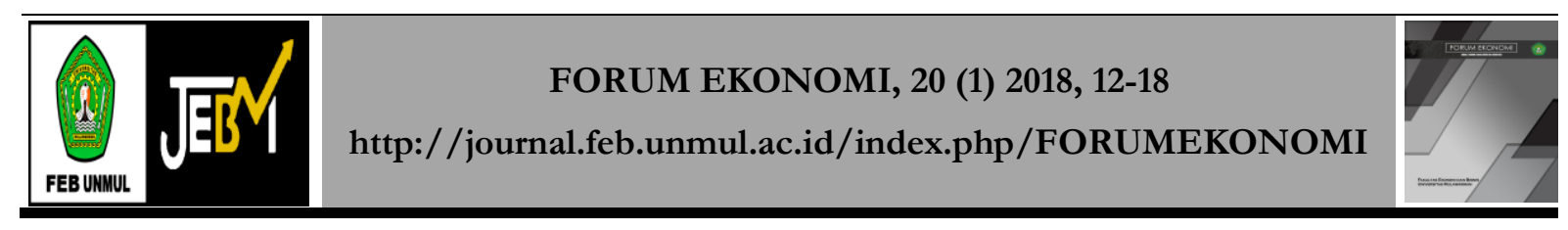

\title{
Analisis faktor-faktor yang mempengaruhi kesempatan kerja
}

\author{
Doni Roma Dona ${ }^{1}$, Aji Sofyan Effendi ${ }^{2}$, Muliati ${ }^{3}$ \\ Fakultas Ekonomi dan Bisnis Universitas Mulawarman, Samarinda. \\ ${ }^{1}$ Email: romadona_doni@yahoo.com \\ ${ }^{2}$ Email: aji.sofyan.effendi@feb.unmul.ac.id \\ ${ }^{3}$ Email: muliati@feb.unmul.ac.id
}

\begin{abstract}
Abstrak
Tujuan dari penelitian ini adalah untuk menganalisis Faktor-faktor yang Mempengaruhi Kesempatan Kerja Di Kota Samarinda. Alat analisis yang digunakan dalam penelitian ini adalah analisis regresi berganda dengan menggunakan SPSS versi 22. Hasil analisis menunjukkan bahwa inflasi tidak berpengaruh signifikan terhadap kesempatan kerja dengan tingkat signifikansi $0,741>\alpha=$ 0,05 , upah berpengaruh signifikan terhadap kesempatan kerja. dengan tingkat signifikansi $0.000<\alpha=$ 0,05 , pertumbuhan ekonomi memiliki pengaruh yang signifikan terhadap peluang kerja dengan tingkat signifikansi $0,076<\alpha=0,10$.
\end{abstract}

Kata Kunci: Inflasi; upah; pertumbuhan ekonomi; peluang kerja

\section{Analysis of factors affecting employment}

\begin{abstract}
The purpose of this study was to analyze the Factors Affecting the Job Opportunity In the city of Samarinda. The analytical tool used in this research is multiple regression analysis by using SPSS version 22. Results of the a nalysis showed that inflation had no significant effect on employment opportunities with a significance level of $0.741>\alpha=0.05$, wages have a significant effect on employment opportunities with a significance level of $0.000<\alpha=0.05$, economic growth has a significant effect on Job opportunities with a significance level of $0.076<\alpha=0.10$.

Keywords: Inflation; wages; economic; growth; employment opportunities
\end{abstract}




\section{PENDAHULUAN}

Dalam mendorong pembangunan ekonomi, ketenagakerjaan merupakan aspek yang mendasar dalam kehidupan manusia karena mencakup dimensi sosial dan ekonomi, sehingga salah satu sasaran dalam pembangunan diarahkan pada perluasan kesempatan kerja dan terciptanya lapangan kerja baru dalam jumlah dan kualitas yang seimbang dan memadai. Hal itu ditujukan agar dapat menyerap tambahan angkatan kerja yang memasuki pasar kerja setiap tahunnya.

Memperluas kesempatan kerja bukan hanya penting dari sisi ekonomi, namun juga sosial. Selain menciptakan lapangan kerja baru, memperluas kesempatan kerja juga akan meningkatkan pendapatan masyarakat. Hal ini secara tidak langsung akan juga mengurangi kemungkinan terjadinya masalah sosial dalam kehidupan masyarakat. Pengalaman menunjukkan bahwa banyak gejolak sosial misalnya kriminalitas yang terjadi disebabkan oleh banyaknya pengangguran. Untuk mengantisipasi hal tersebut, maka setiap upaya pembangunan yang dilakukan selalu diarahkan pada perluasan kesempatan kerja dan berusaha.

Menurut Sadono Sukirno (2002), inflasi adalah suatu proses kenaikan harga-harga yang berlaku dalam suatu perekonomian.Inflasi merupakan kecenderungan kenaikan harga yang terjadi secara terus menerus. Kenaikan harga ini tidak hanya terdapat pada satu, dua atau beberapa barang saja, namun diikuti oleh hampir seluruh barang yang ada di suatu negara.

Upah mempunyai pengaruh terhadap jumlah angkatan kerja yang bekerja. Jika semakin tinggi tingkat upah yang ditentukan, maka sangat berpengaruh pada meningkatnya biaya produksi. Akibatnya, perusahaan terpaksa melakukan pengurangan tenaga kerja sebagai tindakan efisiensi, yang berakibat pada rendahnya jumlah angkatan kerja yang bekerja. Sehingga diduga tingkat upah mempunyai pengaruh yang negatif terhadap jumlah angkatan kerja yang bekerja (Payaman $\mathbf{J}$ Simanjuntak, 2001). Pemberian upah minimum yang layakdiharapkan pekerja dapat memenuhi kebutuhan gizinya, sehingga dapat meningkatkan produkitivitas, namun bila ditinjau dari teori ekonomi klasik danneoklasik bahwa penetapan upah minimum bukan dianggap kebijakan yang tepat

Faktor yang berpengaruh terhadap permintaan tenaga kerja adalah pertumbuhan ekonomi. Pertumbuhan ekonomi biasanya ditinjau secara nasional dan secara wilayah/daerah.Pembangunan daerah diharapkan akan membawa dampak positif terhadap pertumbuhan ekonomi. Persoalan pertumbuhan ekonomi (economicgrowth) telah mendapat perhatian yang besar sejak munculnya ilmu ekonomi. Menurut Nanga (dalam Fretes, 2007) pertumbuhan ekonomi dibutuhkan dan merupakan sumber utama peningkatan standar hidup (standard of living)penduduk yang jumlahnya terus meningkat. Dengan kata lain, kemampuan ekonomi suatu negara untuk meningkatkan standar hidup penduduknya adalah sangat bergantung dan ditentukan oleh laju pertumbuhan ekonomi jangka panjangnya (long run rate of economic growth).

\section{Tinjauan Pustaka \\ Kesempatan Kerja}

Pada negara yang sedang berkembang umumnya masalah pengangguran merupakan masalah yang sulit dipecahkan hingga kini, karena masalah pengangguran menyebabkan tingkat pendapatan nasional dan tingkat kemakmuran masyarakat tidak mencapai potensi maksimal, seperti halnya juga di Indonesia, pemerintah mengupayakan secara lambat laun baik diperkotaan maupun dipedesaan. Kebijakan negara dalam penyerapan tenaga kerja meliputi upaya-upaya untuk mendorong pertumbuhan dan perluasan lapangan kerja disetiap daerah serta, perkembangan jumlah dan kualitas angkatan kerja yang tersedia agar dapat memanfaatkan seluruh potensi pembangunan di daerah masing-masing. Dari kebijakan tersebut maka dalam rangka mengatasi masalah perluasan kesempatan kerja dan mengurangi pengangguran.

\section{Inflasi}

Salah satu peristiwa moneter yang sangat penting dan yang dijumpai di hampir semua negara di dunia adalah inflasi. Boediono (1999) menyatakan bahwa 27 definisi singkat dari inflasi adalah kecenderungan dari harga-harga untuk naik secara umum dan terus menerus. Kenaikan harga dari satu atau dua barang saja tidak disebut inflasi, kecuali bila kenaikan tersebut meluas kepada (atau mengakibatkan kenaikan) sebagian besar dari harga barang-barang lain. Kenaikan harga-harga karena musiman, menjelang hari-hari besar, atau yang terjadi sekali saja (dan tidak mempunyai pengaruh lanjutan) tidak disebut inflasi. Kenaikan harga semacam ini tidak dianggap sebagai masalah atau 
"penyakit" ekonomi dan tidak memerlukan kebijaksanaan khusus untuk menanggulanginya. Sedangkan Sukirno (2002) menyatakan bahwa inflasi dapat didefinisikan sebagai suatu proses kenaikan harga-harga yang berlaku dalam sesuatu perekonomian.

\section{Upah}

Salah satu cara memberikan penghargaan terhadap prestasi kerja karyawan yaitu dengan melalui upah. Upah merupakan masalah yang menarik dan penting bagi perusahaan, karena upah mempunyai pengaruh yang sangat besar terhadap pekerja. Sebagai salah satu dari barometer di dalam pengukuranpengukuran berbagai macam kesejahteraan, maka pemerintah berperan aktif untuk mengaturupah. Pemerintah telah mengatur Upah Minimal Kota/Kabupaten (UMK). Di berbagai propinsi ternyata penetapan upah minimum berbeda-beda, baik besarnya, persentase kenaikan setiap tahun, sistem penetapannya dan ruang lingkup yang ditetapkan. Beberapa provinsi menetapkan upah minimum tunggal dan sebagian provinsi lainnya menetapkan upah minimum sektoral.

\section{Pertumbuhan Ekonomi}

Pertumbuhan ekonomi adalah suatu kondisi di mana terjadinya perkembangan GNP yang mencerminkan adanya pertumbuhan output per kapita dan meningkatnya standar hidup masyarakat (Murni, 2009)

\section{METODE}

\section{Alat analisis}

Untuk Mengetahui Pengaruh Inflasi, Upah, Pertumbuhan Ekonomi terhadapKesempatan Kerja di Kota Samarinda.Penelitian ini menggunakan Regresi Liner. Menurut (Agus, 2005) regresi dalam pengertian modern adalah studi bagaimana variabel dependen dipengaruhi satu atau lebih dari variabel independen dengan tujuan untuk mengestimasi dan atau memprediksi nilai rata-rata variabel dependen didasarkan pada nilai variabel independen yang diketahui.

\section{Uji Linearitas}

Uji linearitas bertujuan untuk mengetahui apakah dua variabel mempunyai hubungan yang linear atau tidak secara signifikan. Uji ini biasanya digunakan sebagai prasyarat dalam analisis korelasi atau regresi linear. Uji linearitas dilakukan dengan mencari persamaan garis regresi variabel bebas $\mathrm{X}$ terhadap variabel terikat Y. Berdasarkan garis regresi yang telah dibuat, selanjutnya diuji keterkaitan koefisien garis regresi serta linearitas garis regresi. Salah satu teknik analisis regresi yang paling sering digunakan adalah regresi linear. Regresi linear dapat digunakan apabila asumsi linearitas dapat terpenuhi. Jika asumsi ini tidak terpengaruhi, maka kita tidak dapat menggunakan analisis regresi linear, akan tetapi kita bisa menggunakan analisis regresi non linear. Asumsi linearitas adalah asumsi yang akan memastikan apakah data yang kita miliki sesuai dengan garis linear atau tidak.

\section{Uji Asumsi Klasik}

Pengujian model dimaksud untuk memperoleh kepastian tentang konsistensi model estimasi yang dibentuk berdasarkan teori ekonomi yang melandasinya. Dalam melihat spesifikasi model yang dilakukan uji linearitas serta melihat distribusi data dalam model regresi, maka dilakukan uji normalitas. Pengujian penyimpangan asumsi klasik dimaksud untuk menjamin bahwa model yang diestimasi bebas dari gangguan autokorelasi, multikolinearitas dan heteroskedastisitas.

\section{Pengujian Hipotesis}

Pengujian hipotesis penuilis menggunakan uji $\mathrm{R}, \mathrm{R}^{2}$, Uji $\mathrm{F}$ dan Uji $\mathrm{T}$ untuk mengetahui pengaruh antara variabel bebas terhadap variabel tidak bebas.

\section{Koefisien Korelasi (R)}

Korelasi ganda (multiple correlation) merupakan angka yang menunjukan arah dan kuatnya antara dua variabel secara bersama-sama atau lebih dengan variabel lain.

\section{Koefisien Determinasi $\left(\mathbf{R}^{2}\right)$}

Untuk memperoleh nilai koefisien determinasi $(R)^{2}$ yang dilambangkan dengan $0 \leq R^{2} \geq 1$, yang dapat dirumuskan sebagai berikut:

$\mathrm{R}^{2}=(\mathrm{KK})^{2} \times 100 \%$ (Hasan, 2004)

Dimana :

KK $=$ Koefisien Korelasi 


\section{Uji F}

Untuk menguji koefisien regresi secara keseluruhan digunakan pengujian hipotesis uji $\mathrm{F}$ pada tingkat kepercayaan $95 \%$ dengan rumus sebagai berikut :

Dimana :

Fhitung $=\frac{R^{2} /(k-1)}{\left(1-R^{2}\right)(N-K)}$ (Supranto, 1999)

F : Nilai Hitung

K : Jumlah Variabel Independen

n : Jumlah Tahun

R2 : Koefisien Determinasi

Hasil perhitungan tersenut diatas apabila dibandingkan dengan $\mathrm{F}$ table pada tingkat kepercayaan $95 \%$, setelah $\mathrm{F}$ hitung $>\mathrm{F}$ table maka :

H0 $: \beta=0$ ditolak

H1 $\quad: \beta=0$ diterima

Uji t

a. Uji t (X1) terhadap Y1

th1 $=\frac{b_{1}-\beta_{1}}{s b_{1}}$ (Supranto, 2001)

dimana :

$\mathrm{Sb} 1=\sqrt{\operatorname{var} b_{1}}$

$\sqrt{\text { var } b_{1}}=\frac{\sum x_{1}^{2}}{\left(\sum x_{1}^{2}\right)-\left(\sum x_{1}\right)^{2}} \alpha^{2}$

$\alpha 2=\frac{\sum e^{2}}{n-k}$

$\sum e^{2}=\sum Y_{1}^{2}-b_{1} \sum x_{1} Y_{1}$

Rumus hipotesisnya $\mathrm{H} 0: \beta 1=0$ berarti variabel $\mathrm{X} 1$ tidak mempengaruhi variabel $\mathrm{Y} 1$. Dan jika $\mathrm{H} 1: \beta 1 \neq 0$ berarti variabel $\mathrm{X} 1$ mempengaruhi variabel $\mathrm{Y} 1$

b. Uji t (X2) terhadap Y1

th1 $=\frac{b_{1}-\beta_{1}}{s b_{1}}$ (Supranto, 2001)

dimana :

$\mathrm{Sb} 1=\sqrt{\operatorname{var} b_{2}}$

$\sqrt{\operatorname{var} b_{1}}=\frac{\sum x_{2}^{2}}{\left(\sum x_{1}^{2}\right)-\left(\sum x_{1}\right)^{2}} \alpha^{2}$

$\alpha 2=\frac{\sum e^{2}}{n-k}$

$\sum e^{2}=\sum Y_{2}^{2}-b_{1} \sum x_{1} Y_{1}$

Rumus hipotesisnya $\mathrm{H} 0: \beta 1=0$ berarti variabel $\mathrm{X} 1$ tidak mempengaruhi variabel Y2. Dan jika $\mathrm{H} 1: \beta 1 \neq 0$ berarti variabel $\mathrm{X} 1$ mempengaruhi variabel $\mathrm{Y} 2$

c. Uji t (X3) terhadap Y1

th1 $=\frac{b_{1}-\beta_{1}}{s b_{1}}$ (Supranto, 2001)

dimana :

$\mathrm{Sb} 1=\sqrt{\operatorname{var} b_{1}}$

$\sqrt{\operatorname{var} b_{1}}=\frac{\sum x_{2}^{2}}{\left(\sum x_{1}^{2}\right)-\left(\sum x_{1}\right)^{2}} \alpha^{2}$

$\alpha 2=\frac{\sum e^{2}}{n-k}$

$\sum e^{2}=\sum Y_{2}^{2}-b_{1} \sum x_{1} Y_{1}$

Rumus hipotesisnya $\mathrm{H} 0: \beta 1=0$ berarti variabel $\mathrm{X} 1$ tidak mempengaruhi variabel $\mathrm{Y} 2$. Dan jika $\mathrm{H} 1: \beta 1 \neq 0$ berarti variabel $\mathrm{X} 1$ mempengaruhi variabel $\mathrm{Y} 2$. 
Kemudian untuk mengetahui tingkat pengaruh antara $\mathrm{H} 1$ dan $\mathrm{X} 2$ terhadap $\mathrm{Y} 1$ maka kita hitung nilai koefisiendeterminasi yang dilambangkan dengan $\mathrm{R} 2$.semakin besar nilai $\mathrm{R} 2$, maka semakin besar pengaruh X1 dan X2 terhadap Y.

Dinyatakan dengan rumus :

$\mathrm{R} 2=\frac{b_{1} \sum x_{1} y+b_{2} \sum x_{2} y}{\sum y^{2}}$

Dimana :

$\mathrm{R} 2=\frac{b_{1} \sum x_{1} y+b_{2} \sum x_{2} y}{\sum y^{2}}$

Tinggi rendahnya atau erat tidaknya hubungan antar variabel, menggunakan katagori yang dibuat Guildford (1956) sebagai berikut:

kurang dari 0,20 hubungan sangat kecil dan dapat diabaikan

0,20 sampai 0,40 hubungan tidak kuat

0,40 sampai 0,70 hubungan cukup kuat

0,70 sampai 0,90 hubungan erat atau kuat

0,90 sampai 1,00 hubungan sangat erat dan dapat diandaikan

\section{HASIL DAN PEMBAHASAN}

\section{Pengaruh Inflasi terhadap Kesempatan Kerja}

Berdasarkan hasil penelitian,Inflasi berpengaruh terhadap Kesempatan Kerja Kota Samarinda dengan nilai koefisien standardized sebesar -0,049 yang artinya kenaikan 1 persen Inflasi akan menyebabkan terjadinya penurunan Kesempatan Kerja sebesar 0,049.

Dari hasil pengujian terbukti bahwa Inflasi memiliki pengaruh yang tidak signifikan terhadap Kesempatan Kerja dengan taraf signifikansi 0,741 $>\alpha=0,05$. Dengan demikian dapat disimpulkan bahwa Inflasi berpengaruh tetapi tidak signifikan terhadap Kesempatan Kerja.

Hal ini dikarenakan investor tidak berani berinvestasi di Kota Samarinda karena tingkat inflasi yang tinggi, sehingga tidak berdampak positif terhadap Kesempatan Kerja di Kota Samarinda.

\section{Pengaruh Upah terhadap Kesempatan Kerja}

Berdasarkan hasil penelitian, Upah berpengaruh terhadap Kesempatan Kerja dengan nilai koefisien standardized sebesar 0,930yang artinya kenaikan 1 persen Upah Minimum akan menyebabkan terjadinya peningkatan Kesempatan Kerja sebesar 0,930.

Dari hasil pengujian terbukti bahwa Upah Minimum memiliki pengaruh yang signifikan terhadap Kesempatan Kerja dengan taraf signifikansi 0,000 $>\alpha=0,05$. Dengan demikian dapat disimpulkan bahwa Upah Minimum berpengaruh dan signifikan terhadap Kesempatan Kerja.

Hal ini dikarenakan meningkatnya permintaan konsumen terhadap barang atau jasa dan upah karyawan pun meningkat, sehingga karyawan itu sendiri dapat membuat usaha-usaha baru yang dapat menyerap tenaga kerja lainnya. Maka upah berdampak positif terhadap kesempatan kerja Kota Samarinda.

\section{Pengaruh Pertumbuhan Ekonomi terhadap Kesempatan Kerja}

Berdasarkan hasil penelitian, Pertumbuhan Ekonomi berpengaruh terhadap Kesempatan Kerja dengan nilai koefisien standardized sebesar 0,833 yang artinya kenaikan 1 persen Pertumbuhan Ekonomi akan menyebabkan terjadinya peningkatan Kesempatan Kerja sebesar 0,833.

Dari hasil pengujian terbukti bahwa Pertumbuhan Ekonomi memiliki pengaruh yang signifikan terhadap Kesempatan Kerja dengan taraf signifikansi 0,076 $<\alpha=0,10$. Dengan demikian dapat disimpulkan bahwa Pertumbuhan Ekonomi berpengaruh secara langsung dan signifikan terhadap Kesempatan Kerja.

Hal ini dikarenakan Pertumbuhan Ekonomi yang terus meningkat yang artinya Nilai output atau barang yang dihasilkan meningkat dan produsen pun membutuhkan penambahan pekerja atau karyawan, sehingga Pertumbuhan Ekonomi berpengaruh positif terhadap Kesempatan Kerja di Kota Samarinda.

\section{SIMPULAN}


Berdasarkan hasil analisis baik secara kualitatif dan kuantitatif pembahasan maka dapat disimpulkan bahwa :

Inflasi Kota Samarinda berpengaruh negatif dan tidak signifikan terhadap Kesempatan Kerja Kota Samarinda. Penelitian ini tidak sependapat dengan pernyataan Sukirno (2004), menyatakan dengan tingginya harga (inflasi) maka untuk memenuhi permintaan tersebut produsen meningkatkan kapasitas produksinya dengan menambah tenaga kerja (tenaga kerja merupakan satu-satunya input yang meningkatkan output). Hal ini dikarenakan investor tidak berani berinvestasi di Kota Samarinda karena tingkat inflasi yang tinggi, sehingga tidak berdampak positif terhadap Kesempatan Kerja di Kota Samarinda

Upah Minimum Kota Samarinda berpengaruh positif dan signifikan terhadap Kesempatan Kerja Kota Samarinda. Penelitian ini tidak sependapat dengan Payman J Simanjuntak (2001), yang menyatakan bahwa upah mempunyai pengaruh terhadap jumlah angkatan kerja. Jika semakin tinggi upah yang ditentukan, maka sangat berpengaruh pada meningkatnya biaya produksi. Hal ini dikarenakan meningkatnya permintaan konsumen terhadap barang atau jasa dan upah karyawan pun meningkat, sehingga karyawan itu sendiri dapat membuat usaha-usaha baru yang dapat menyerap tenaga kerja. Maka upah berdampak positif terhadap kesempatan kerja Kota Samarinda.

Pertumbuhan Ekonomi Kota Samarinda berpengaruh positif dan signifikan terhadap Kesempatan Kerja Kota Samarinda. Penelitian ini sependapat dengan Widodo (1990), secara makro laju pertumbuhan kesempatan kerja dapat dikaitkan dengan laju pertumbuhan ekonomi. Dengan kata lain pertumbuhan ekonomi akan mempengaruhi laju pertumbuhan kesempatan kerja. Hal ini dikarenakan Pertumbuhan Ekonomi yang terus meningkat yang artinya Nilai output atau barang yang dihasilkan meningkat dan produsen pun membutuhkan penambahan pekerja atau karyawan, sehingga Pertumbuhan Ekonomi berpengaruh positif terhadap Kesempatan Kerja di Kota Samarinda.

\section{DAFTAR PUSTAKA}

Aisyah, Rita. 2006. "Faktor-Faktor yang Mempengaruhi Kesempatan Kerja Kota Balikpapan". Skripsi.

Budiono. 1992. "Teori Pertumbuhan Ekonomi". Yogyakarta. BPFE UGM.

Efendi, Agus. 2005. "Revolusi Kecerdasan Abad 21". Bandung. Alfabet.

Firmansyah, Dadang. 2008. "Faktor-Faktor Yang Mempengaruhi Kesempatan Kerja Kota Bontang". Skripsi

Hasan, Iqbal. 2001. "Pokok-Pokok Materi Statistik Edisi Kedua". Jakarta. PT. Bumi Aksara

Hasibuan, M.S. 1999. "Organisasi dan Motivasi Dasar Peningkatan Produktivitas". Jakarta. Bumi Aksara.

Kemala, Eva Sari. 2006. "Pengaruh Investasi dan Upah Terhadap Kesempatan Kerja Pada Industri Besar dan Menengah di Sumatera Selatan". Skripsi.

Kuncoro. 2002. "Manajemen Perbankan Teori dan Aplikasi". Jakarta. PT Indek Kelompok Gramedia.

Lincolin, Arsyad. 2004. "Ekonomi Pembangunan". Yogyakarta. STIE YKPN.

Murni, Asfia. 2006. "Ekonomi Makro". Bandung. Refika Aditama.

Riyadi dan Dedy Supriyadi Bratakusumah. 2005. "Perencanaan Pembangunan Daerah". Jakarta. PT Gramedia Pustaka Utama.

Saberan. 2002. "Produk Domestik Regional Bruto". Jakarta. Rajawali

Samuelson, Paul A. Dan William D. Nordhaus. 2004. "Ilmu Makro Ekonomi Edisi ke Tujuh Belas". Jakarta. PT. Media Global Eduksi.

Simanjuntak, P.Y. 1985. "Pengantar Ekonomi Sumber Daya Manusia". Jakarta. Fakultas Ekonomi UI.

Sukirno, Sadono. 1994. "Pengantar Teori Ekonomi". Jakarta. PT Raja Grafindo Persada

Sukirno, Sadono. 2002. "Pengantar Teori Makro Ekonomi". Jakarta. PT Raja Grafindo Persada. 
Analisis faktor-faktor yang mempengaruhi kesempatan kerja; Doni Roma Dona, Aji Sofyan Effendi, Muliati

Sukirno, Sadono. 2002. "Teori Mikro Ekonomi". Jakarta. Rajawali

Sukirno, Sadono. 2004. "Makro Ekonomi Teori Pengantar". Jakarta. PT Raja Grafindo Perkasa.

Sukirno, Sadono. 2006. "Ekonomi Pembangunan". Jakarta. Fakultas Ekonomi UI

Sumarsono, Sony. 2003. "Ekonomi Manajemen Sumber Daya Manusia dan Ketenagakerjaan". Yogyakarta. Graha Ilmu.

Todaro, Michael, P dan Smith, Stephen. 2004. "Pembangunan Ekonomi Dunia Ketiga". Jakarta. Erlangga.

Widodo, HG.Suseno Triyanto. 1990. "Indikator Ekonomi Dasar perhimpunan Perekonomian Indonesia". Yogyakarta. Kanisius.

Wijaya, Farid. 1990. "Ekonomi Pembangunan". Yogyakarta. BPFE UGM 